Vol. 7(1998): 469-476.

\title{
Pest status and incidence of the honey bee tracheal mite in Finland
}

\author{
Seppo Korpela \\ Agricultural Research Centre of Finland, Plant Production Research, Plant Protection, FIN-31600 Jokioinen, \\ Finland, e-mail: seppo.korpela@mtt.fi
}

\begin{abstract}
Colonies of honey bees (Apis mellifera L.) were surveyed for the presence of the honey bee tracheal mite (Acarapis woodi Rennie) in Finland between 1991 and 1997. Colony background information and winter loss data were obtained from beekeepers who had taken tracheal mite infested samples. A total of 2116 samples from honey bee colonies of 402 beekeepers were investigated. Infestations were found in $8 \%$ of the beekeeping operations and in $10 \%$ of the samples inspected. In the last years of the survey more than $20 \%$ of apiaries were infested. This increase may be partly explained by tracheal mite infestations found in commercial queen-rearing apiaries.

A field experiment with colonies infested at different levels showed that colonies in which $20 \%$ or more of bees are infested with tracheal mites have an increased risk of dying during the winter under Finnish conditions. This infestation level was found among colonies in $92 \%$ of the infested apiaries. Comparison of the tracheal mite prevalence in apiaries with their winter losses indicated that infestations were associated with colony mortality.

The results of this survey point to the high pest potential of the tracheal mite in Finland, in contrast to findings on tracheal mites from elsewhere in Europe. Therefore, strategies to prevent further spread of the mite are highly recommended and methods for effective control should be sought.
\end{abstract}

Key words: Acarapis woodi, Apis mellifera, Finland, mite prevalence, winter loss

\section{Introduction}

The honey bee tracheal mite, Acarapis woodi (Rennie), was first detected in Finland in June 1991, among attendant bees of queens imported from California (Korpela 1991, Korpela and Fakhimzadeh 1991). Soon thereafter light tracheal mite infestations were found in samples sent by a beekeeper who had lost one colony in spring and had noticed crawling bees at the entrances of remaining colonies. After this discovery, which showed that the tracheal mite was endemic to the country I sampled my private apiaries for tracheal mites in July 1991; one of three apiaries was highly infested.

Having caused considerable damage in many European countries up to the 1960s, tracheal mite has since come to be considered of minor importance as a pest in Europe, although it may 


\section{Korpela, S. Honey bee tracheal mite in Finland}

still be common in some areas (Bailey and Perry 1982 , Otis 1990 , Ritter 1991 , Orantes Bermejo et al. 1997). Some local and temporal heavy infestations and damage have nevertheless been reported (Gijon-Botella et al. 1987). In the Scandinavian countries and Finland, established tracheal mite infestations were not reported before 1991. In the USA, in contrast, the mite has caused severe losses of wintering bees, especially in the northern states, where winters are cold and long (Furgala et al. 1989, Otis and ScottDupree 1992). Losses of colonies infested by tracheal mites under such conditions may be attributed to both shortened longevity (Bailey and Lee 1959, Maki et al. 1988) and decreased ability of the bees to thermoregulate the winter cluster temperature (Nasr 1995). Finland's winter climate is more like that of the northern USA, where losses due to the tracheal mite have been most common, than that of Continental Europe.

The purpose of my study was to investigate the incidence of the tracheal mite in Finland and to evaluate the damage caused to wintering bees by mite infestations. Wintering success in relation to infestation level was also studied in apiaries of one beekeeper whose colonies were infested with tracheal mite but were left untreated.

\section{Material and methods}

Surveys were conducted during 1991-1997. After the initial discovery of mites from bee samples taken by two beekeepers, sampling continued in live bees in autumn 1991; 108 of these samples were taken from the colonies of 22 beekeepers who had introduced queens from a queen shipment from the USA found to be infested with tracheal mites. In 1992-1997, most samples were obtained from beekeepers in spring, and consisted of dead bees collected from the bottom boards of hives after cleansing flights.

Samples were sent by mail to the bee laboratory of the Agricultural Research Centre of Finland (MTT), where they were stored in freezers until examined for mites. For analysis, sub-samples of 25 bees were normally taken if the samples originated from single colonies. In 1991, 50 bees were taken from most samples for analysis. If the samples were composites from apiaries, 50 bees were taken. Bees were examined for mites using the thoracic disc method as described by Shimanuki and Knox (1991) but modified as follows: prothoracic discs were cut from the bees, clarified for $12-24 \mathrm{~h}$ in $7 \% \mathrm{KOH}$ at $37^{\circ} \mathrm{C}$ and then examined under a binocular microscope at $30 \mathrm{X}$ magnification.

If tracheal mites were found in samples, the beekeeper was contacted and asked for additional samples from any unsampled colonies to determine the spread of the mite within the beekeeping operation. Information on the winter mortality of individual colonies was also requested from the beekeeper.

Some of the newly-discovered tracheal mite infestations were either found too late in the season or data, and/or samples were not available for the whole beekeeping operation; in either case they could not be included in the damage analysis. Complete data on and samples from 25 operations were used to calculate how winter losses were related to infestation levels. The data, comprising 649 colony samples, were analysed for individual operations only in the year of discovery of the infestation, when no chemical control had been applied against the mite.

Monthly samples of 50 live bees from the top bars of the uppermost honey super in two apiaries infested with tracheal mites were taken in July-October 1991 to record infestation changes. In a third apiary where infestations were found, samples were taken in July and October only. A total of 20 additional colonies in four apiaries of the same beekeeping operation in which no tracheal mites were detected in sampling conducted in autumn 1991 were available as controls. In winter 1991-1992, the apiaries were visited monthly to observe the condition of the colonies.

The colonies were managed in Langstroth hive bodies, following normal management practices: surplus honey was harvested from all broodless combs in late August, whereafter sug- 
Vol. 7 (1998): 469-476.

Table 1. Tracheal mite survey at the Agricultural Research Centre of Finland (MTT) in 1991-1997.

\begin{tabular}{lccccc}
\hline Year & $\begin{array}{c}\text { Beekeepers } \\
\text { sending } \\
\text { samples }^{\text {a }}\end{array}$ & $\begin{array}{c}\text { New } \\
\text { infestations } \\
\text { found }^{\mathrm{b}}\end{array}$ & $\begin{array}{c}\text { Beekeepers } \\
\text { with positive } \\
\text { samples }\end{array}$ & $\begin{array}{c}\text { Positive } \\
\text { samples } \\
\%\end{array}$ & $\begin{array}{c}\text { Number of } \\
\text { samples } \\
\text { examined }\end{array}$ \\
\hline 1991 & 33 & 2 & 6 & 8 & 231 \\
1992 & 92 & 3 & 3 & 4 & 489 \\
1993 & 76 & 3 & 4 & 1 & 394 \\
1994 & 53 & 1 & 2 & 5 & 175 \\
1995 & 41 & 4 & 10 & 7 & 220 \\
1996 & 76 & 12 & 16 & 21 & 404 \\
1997 & 31 & 7 & 23 & 28 & 203 \\
Total & 402 & 32 & & & 2116 \\
\% of total & & & 8 & 10 & \\
\hline
\end{tabular}

${ }^{\text {a }}$ only beekeepers not having sent samples earlier

${ }^{\mathrm{b}}$ number of beekeepers with at least one positive bee / sample

ar syrup (3:2, wt:wt) was fed for winter feed during 3 weeks. Most of the infested colonies (nine out of 14) wintered in two insulated hive bodies and were fed 341 of sugar syrup. The rest of the colonies wintered in one hive body and were fed 211 of sugar syrup. The colonies had been continuously monitored for varroa mites since the discovery of the mite in 1989. In autumn 1991, the infestation level was weak to moderate, the mean natural mite mortality on screened bottom inserts being 4.7 mites/day in late August. The nine colonies with the highest varroa counts were treated with Apistan ${ }^{\circledR}$, starting on 2 September.

\section{Results}

\section{Tracheal mite incidence in Finland}

In 1991-1997, the number of beekeepers participating in the survey was 402 , which corresponds to about $10 \%$ of beekeepers in Finland. In the autumn of 1991 no positive cases could be added to the two discoveries made in the summer, but from spring 1992 new infestations were found each year of the survey. Of all beekeepers participating in the survey, $32(7.6 \%)$ had at least one positive sample (Table 1). Tracheal mites were found in the three southern provinces (Fig. 1), but

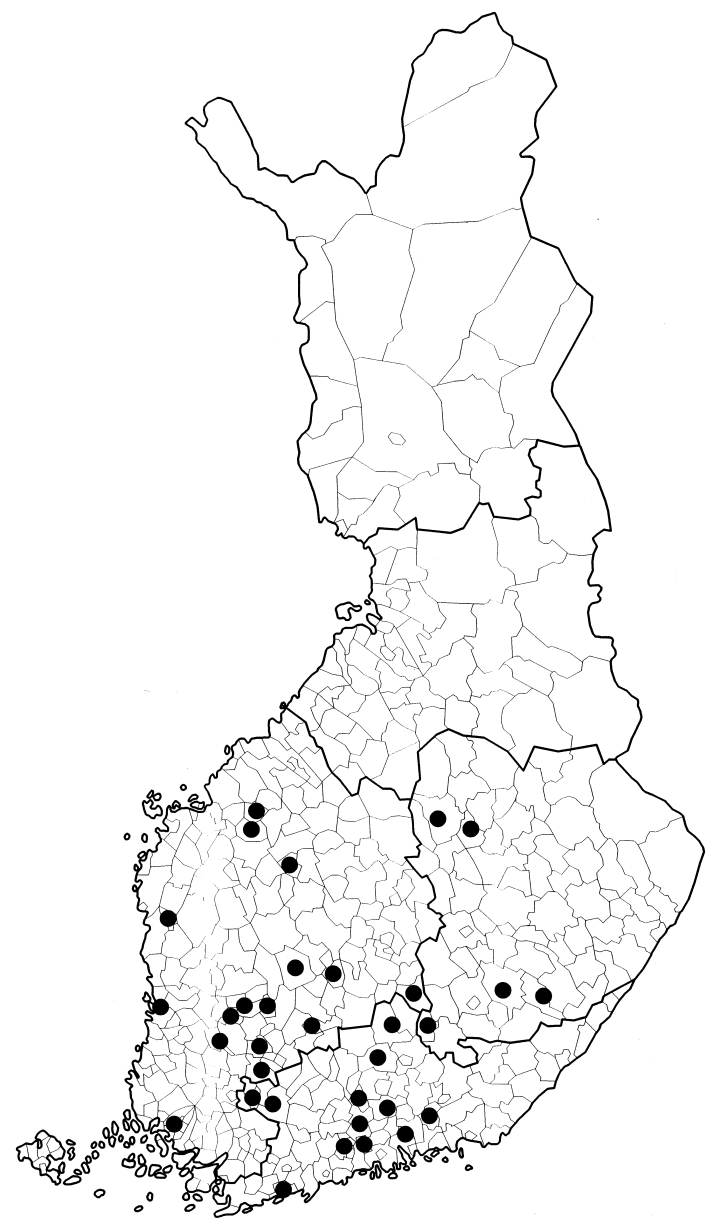

Fig. 1. Distribution of Acarapis woodi in Finland, based on samples collected in 1991-1997. 
Korpela, S. Honey bee tracheal mite in Finland

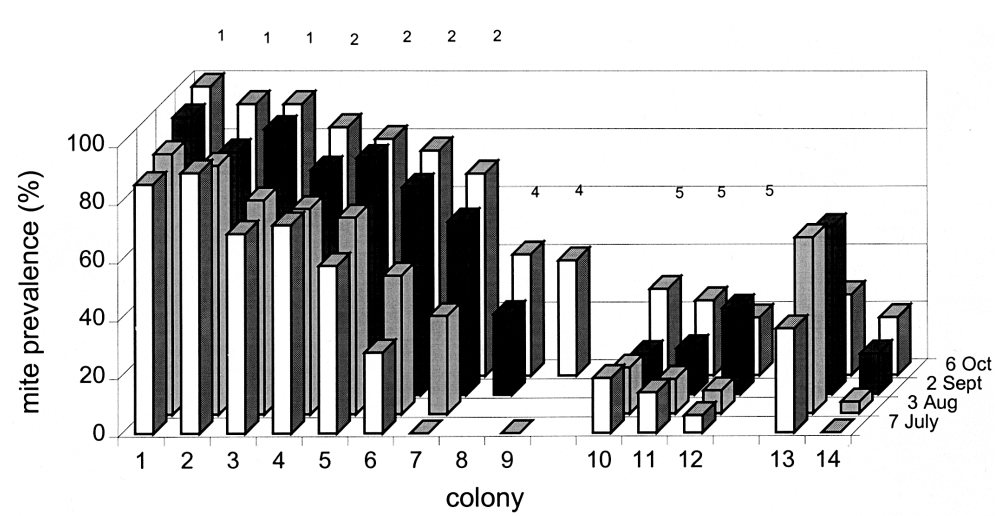

Fig. 2. Mite infestation changes in experimental colonies from July to October 1991. Numbers above bars indicate months in 1992 when the colonies were observed as dead (colonies 1-9) or were exterminated (colonies 10-12). not in the two northern provinces or the Province of Åland.

\section{Wintering success of infested colonies in experimental apiaries}

Infestations were found in 14 of the 41 colonies sampled in 1991. The mean mite prevalence in the infested colonies increased from $37 \%$ to $58 \%$ from July to October 1991 (Fig. 2). A clear connection was found between the severity of the infestation and the time of the colony death. All colonies (1-9) found dead had clean combs with ample food stores. The bee clusters in the dead colonies did not seem to have been as compact as in the normal colonies, dead bees having been found in all bee spaces between combs. Masses of dead bees were seen on hive bottoms indicating that colonies were sufficiently strong for the winter. Colonies 10-12 did not die during the winter but were so weak in May of the following year that they were removed; each hive contained only 100-200 bees and the queen. Of the infested colonies, only two weakened colonies survived, with $52 \%$ and $12 \%$ mite prevalence in May. The $86 \%$ winter loss in infested colonies (12 out of 14 colonies) differed significantly (chi-square with Yates's correction = 28.06 , d.f. $=1, \mathrm{P}<0.001)$ from the loss in noninfested colonies, where only $3 \%$ of colonies ( 1 out of 31) were lost.

\section{Colony losses in apiaries where tracheal mites were found during the survey}

The winter losses in uninfested colonies were less than $20 \%$ in $90 \%$ of the beekeeping operations, but higher among infested colonies (Fig. 3 ). The figure shows that when infestations exist, they tend to diversify winter losses from the normal $<20 \%$ level to any level above it. Further, there was a significant positive relationship (Fig. 4) between the proportion of infested colonies and the proportion of lost colonies $(\mathrm{P}<0.001)$. Of all 34 operations supplying infest-

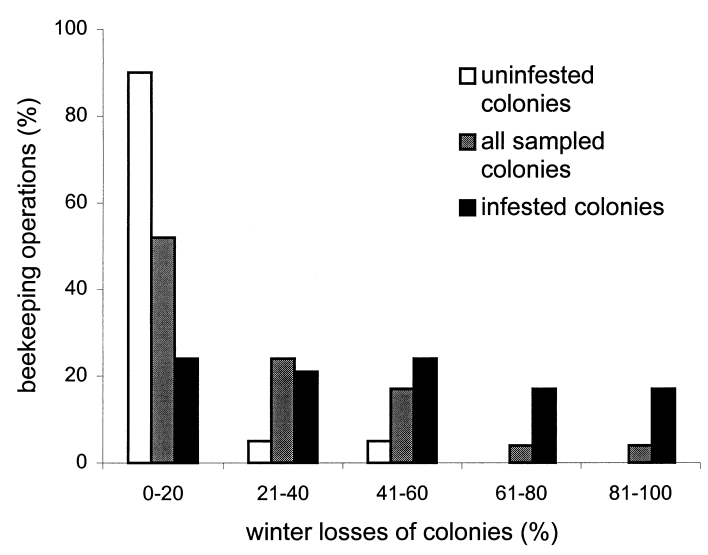

Fig. 3. Frequency distribution of winter losses in tracheal mite infested beekeeping operations calculated separately for all, uninfested and infested colonies. 
Vol. 7 (1998): 469-476.

Fig. 4. Colony winter losses as a function of tracheal mite infestation. Symbols show the year represented by the data points: $1992 \square 1993$ $\triangle 1994 \Delta 1995 \square 1996$ $\bigcirc 1997$.

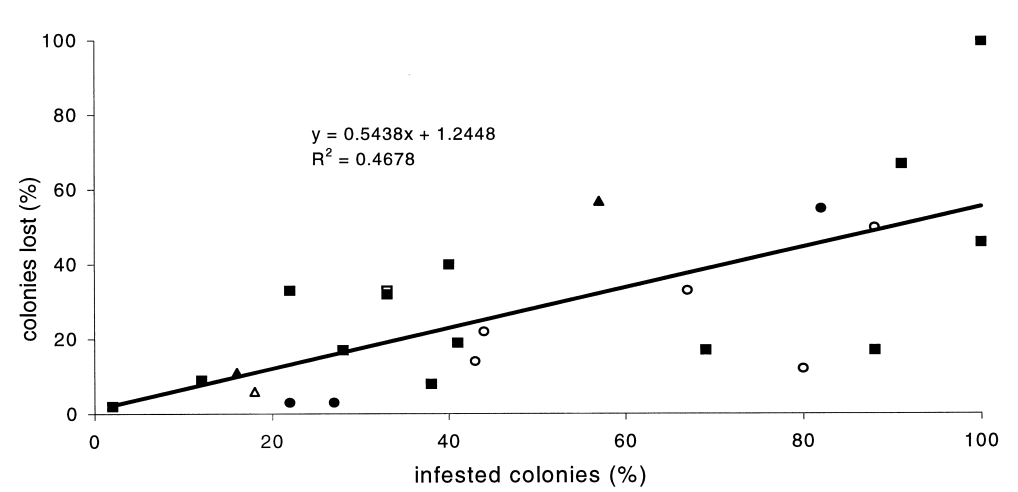

During the last years of the survey, the infestations tended to become more common (Table 1), possibly indicating that mite incidence among bee colonies increased in the course of the survey. Although the selection of apiaries was not randomised, I consider the results fairly representative of the whole bee colony pool of Finland, as beekeepers were annually requested to send samples not only from dead colonies but also from colonies with no apparent problems during the winter. Not until 1996-1997 did the percentage of positive samples exceed the $16 \%$ level of the survey made in November 1991 by Fakhimzadeh et al. (1993). The authors do not, however, mention the number of beekeeping operations found positive for tracheal mite, making it difficult for me to compare my results with theirs.

The increase in the proportion of infested samples and beekeeping operations may be partly due to mite infestations found in four queenrearing operations during the survey. The spread of the mites via queens from the infested apiaries is possible because a considerable proportion of the beekeeping operations with tracheal mites in 1995-1997 had regularly purchased queens from a breeder who lost 87 colonies in spring 1996. Most of his loss was probably due to tracheal mite, as the samples from 20 dead colonies had a mean infestation of $89.8 \%$. A direct observation supporting the spread of mites via queen sales was made in 1997, when a small- 


\section{Korpela, S. Honey bee tracheal mite in Finland}

scale queen breeder lost one of his apiaries due to tracheal mites. Infested queens produced by him were found in both the lost apiary and in some remaining bee colonies, and also in another apiary he had supplied with queens.

In the course of the study, 13 of the 40 beekeepers receiving queens from infested imports in 1991 sent a total of 138 samples. Mites were not found until spring 1998, when positive samples were received from one beekeeper of this group who had not used imported queens before or after the 1991 import. However, other sources of infestation cannot be excluded.

The experiment with colonies at different levels of infestations showed that, in the Finnish climate, colonies have an increased risk of dying during the winter if the mite prevalence in autumn exceeds $20 \%$, the value commonly found among colonies in infested apiaries. This is compatible with results from similar areas with cold winters in North America, e.g. Minnesota (Furgala et al. 1989). The winter losses were also related to the proportion of infested colonies, as also observed by Frazier et al. (1994).

Normal winter losses of bee colonies in Finland vary somewhat between years but averaged $14.2 \%$ in 1983-1991 (Ruottinen 1997). Even at this level of losses the profitability of beekeeping is clearly reduced. Efforts to curb spread of the tracheal mite should therefore be given high priority by the Finnish beekeeping industry if losses are to prevented from becoming even higher. A key aim of such efforts should be to prevent the spread of the mite in connection with queen sales. To this end, all apiaries selling queens should be surveyed annually. Moreover, all bee imports should be closely monitored. Although, permits have not been required for imports to Finland from EU countries since 1995, the year Finland joined the EU, careful evaluation of import sources and voluntary tracheal mite checks should be made. Neglecting to do so has already caused at least one of the infestations found here: apiaries established from package bees imported from Tenerife, where tracheal mites losses have been reported (Gijon-Botella et al. 1987), were found to be infested in 1996 .
Bee colony density is low in Finland. Uniform distribution of colonies over the whole country would give a colony density of ca. 0.13 / $\mathrm{km}^{2}$. Although highest in the south, density hardly exceeds one colony $/ \mathrm{km}^{2}$ anywhere. This, together with the mainly stationary form of apiary management, should diminish the potential of infestations to spread naturally between apiaries (Bailey and Perry 1982). If the proposed precautions were taken, it would be much easier to keep the tracheal mite threat under control. As it is, man-assisted bee movement, in the form of colony trade, is the main means of spreading the mite, and is difficult to control.

A complementary strategy to suppress the damage done by the tracheal mite would be to introduce control practices against the varroa mite that would also be effective against the tracheal mite. Unfortunately, fluvalinate (Apistan ${ }^{\circledR}$ ) currently widely used against the varroa mite in Finland is not effective against tracheal mites (Scott-Dupree and Otis 1992). Formic acid treatments, however, have good efficacy against tracheal mites (Hoppe et al. 1989, Liu and Nasr 1992, Wilson et al. 1993), and tests conducted in apiaries found to be infested by the tracheal mite during this survey showed that regular treatments with formic acid in spring, and in some cases also in autumn brought prevalences down to levels difficult to detect within 1 to 2 years. There is, however, an urgent need to find application methods for formic acid that reduce the problems associated with its use, for instance, its varying efficacy against the varroa mite and queen losses.

The results of this study indicate the high pest potential of the tracheal mite in Finland in marked contrast to findings on the effects of tracheal mites reported elsewhere in Europe. A similar discrepancy in tracheal mite pest status between the rest of Europe and North America has been attributed to the gradual development of honey bee resistance to the tracheal mite in Europe (Lin et al. 1996, Otis and Scott-Dupree 1992). However, now that the mite has been found able to cause considerable losses to beekeeping in an European country with cold and 
Vol. 7 (1998): 469-476.

long winters, often reaching damaging population levels, an explanation might also be sought in differences in climate and seasonal weather.
Acknowledgements. I thank Ari Eskola, Satu Jokinen, Marja-Liisa Lindén, Iraida Piltschikova, Sirkka Reunanen and Jarkko Salomäki for helping to dissect the bees and collect the data.

\section{References}

Bailey, L. \& Lee, D.C. 1959. The effect of infestation with Acarapis woodi (Rennie) on the mortality of honey bees. Journal of Insect Pathology 1: 15-24.

- \& Perry, J.N. 1982. The diminished incidence of Acarapis woodi (Rennie)(Acari: Tarsonemidae) in honey bees, Apis mellifera L. (Hymenoptera: Apidae), in Britain. Bulletin of Entomological Research 72: 655662.

Chaneet, G. de, Kessell, A.C. \& Allen, L.F. 1984. Acarapis mites on honeybees. Australian Veterinary Journal 61: 322-323.

Fakhimzadeh, K., Hokkanen, H., Sikkilä, J., Pirhonen K. \& Lintula, E. 1993. The first survey of Acarapis woodi in Finland. Bee World 74: 129-132.

Frazier, M.T., Finley, J., Collison, C.H. \& Rajotte, E. 1994. The incidence and impact of honey bee tracheal mites and nosema disease on colony mortality in Pennsylvania. Bee Science 3: 94-100.

Furgala, B., Duff, S., Aboulfaraj, S., Ragsdale, D. \& Hyser, R. 1989. Some effects of the honey bee tracheal mite (Acarapis woodi Rennie) on non-migratory, wintering honey bee (Apis mellifera L.) colonies in east central Minnesota. American Bee Journal 129: 195197.

Gijon-Botella, H., Lopez-Roman, R. \& Gomez-Calcerrada V. 1987. Parasitofauna de Apis mellifera en Tenerife. Acarapis woodi Rennie, 1921 muy probable cause de la alta mortandad de Apis mellifera en Canarias. Revista Ibérica de Parasitologia Volumen Ex.: 255261.

Hoppe, H., Ritter, W. \& Stephen, E.W.C. 1989. The control of parasitic bee mites: Varroa jacobsoni, Acarapis woodi and Tropilaelaps clareae with formic acid. American Bee Journal 129: 739-742.

Korpela, S. 1991. Mehiläisen sisuspunkki, Acarapis woodi, Suomessa. Mehiläinen 8: 142-145.

- \& Fakhimzadeh, K. 1991. Tracheal mites in Finland. American Bee Journal 131: 587-588.

Lin, H., Otis, G.W. \& Scott-Dupree, C. 1996. Comparative resistance in Buckfast and Canadian stocks of honey bees (Apis mellifera L.) to infestation by honey bee tracheal mites (Acarapis woodi (Rennie)). Experimental and Applied Acarology 20: 87-101.
Liu, T.P. \& Nasr, M. 1992. Effects of formic acid treatment on the infestation of tracheal mites, Acarapis woodi (Rennie), in the honey bee, Apis mellifera L. American Bee Journal 132: 666-668.

Maki, D.L., Wilson, W.T., Vargas, C.J., Cox, R.L. \& Petersen, H.D. 1988. Effect of Acarapis woodi infestation on honey-bee longevity. In: Needham, G.R et al.(eds.). Africanized honey bees and bee mites. Chichester, UK, Ellis Horwood. p. 512-517.

Nasr, M. 1995. Effect of tracheal mites on thermoregulation and oxygen consumption of honey bees. In: Nasr, M. Tracheal mite resistance technology transfer annual report. Guelph, Ontario Beekeepers' Association. p. 33-41.

Orantes Bermejo, F.J., Benitez Rodrigues, R. \& Garcia Fernandez, P. 1997. A scientific note on the current low levels of honey bee tracheal mite in southern Spain. Apidologie 28: 149-150.

Otis, G.W. 1990. Results of a survey on the economic impact of tracheal mites. American Bee Journal 130: 28-31.

- \& Scott-Dupree, C.D. 1992. Effects of Acarapis woodi on overwintered colonies of honey bees (Hymenoptera: Apidae) in New York. Journal of Economic Entomology 85: 40-46.

Ritter, W. 1991. Die Tracheenmilbe und ihre heutige Bedeutung. Bienenvater 112: 420-422.

Ruottinen, L. 1997. Talvi käy röyhkeästi lompakollamme. Mehiläinen 14: 257.

Scott-Dupree, C.D. \& Otis, G.W. 1992. The efficacy of four miticides for the control of Acarapis woodi (Rennie) in a fall treatment program. Apidologie 23: 97106.

Shimanuki, H. \& Knox, D.A. 1991. Diagnosis of honey bee diseases. USDA, Agric. Handbook No AH-690.

Wilson, W.T., Baxter, J.R. \& Collins, A. 1993. Formic acid fumigation for control of tracheal mites in honey bee colonies. Bee Science 3: 26-32.

Zanin, E., Costanzi, C. \& Allegretti, M. 1984. Risultati ed esperienze nella lotta contro le malattie infettive delle api in provincia di Trento dal 1975 al 1983. Atti della Societa Italiana delle Scienze Veterinarie 38: 713-716. 
Korpela, S. Honey bee tracheal mite in Finland

\title{
SELOSTUS
}

\section{Mehiläisen sisuspunkin aiheuttamat tuhot ja esiintyminen Suomessa}

\author{
Seppo Korpela \\ Maatalouden tutkimuskeskus
}

Tässä tutkimuksessa selvitettiin mehiläisen sisuspunkin (Acarapis woodi) esiintymistä, punkkisaastunnoista aiheutuneita tuhoja ja punkin leviämistä Suomessa. Tutkimus aloitettiin vuonna 1991, jolloin ensimmäiset sisuspunkkilöydöt Suomessa tehtiin sekä USA:sta tuodussa emoerässä että hoitajien tarhauksissa. Yhteensä 2116 mehiläisnäytettä 402 mehiläishoitajalta tutkittiin vuosina 1991-1997. Näytteistä $10 \%$ oli sisuspunkin saastuttamia ja $8 \%$ :ssa näytteitä lähettäneistä tarhauksista löydettiin vähintään yksi saastunut mehiläiskunta.

Viime vuosina sisuspunkkia löytyi kotimaisten emonkasvattajien tarhauksista, mikä ainakin osittain selittänee saastuneiden tarhausten osuuden lisääntymistä tutkimusjakson kolmena viimeisenä vuotena. Eräs sisuspunkkisaastunnan lähde voi kuitenkin olla jo 1970-luvun puolivälissä Italiasta tuodut emot. Havaitsemattomia saastuntoja saattaa siten olla suomalaisessa mehiläiskannassa vielä runsaasti ja ilman yhteyttä viimeaikaisiin mehiläishankintoihin.

Kenttäkoe, jossa tutkittiin erilaisia saastuntoja omaavien pesien talvehtimista, osoitti, että jo $20 \%$ saastuntataso syksyllä merkitsee lisääntynyttä talvikuolleisuusriskiä. Tulos vastaa samankaltaisissa oloissa USA:n pohjoisosissa saatuja tuloksia. Myös hoitajilta kerätty tieto talvitappioista saastuneilla tarhoilla tukee kenttäkokeen tuloksia, sillä tarhauksissa todettiin saastuneiden mehiläiskuntien osuuden lisääntyessä selvä talvitappioiden lisääntyminen.

Tutkimuksen tulokset osoittavat, että sisuspunkin suuri tuhopotentiaali Suomessa poikkeaa tilanteesta muualla Euroopassa, jossa punkki esiintyy, mutta ei juuri aiheuta tuhoja. Leviämisen estävät toimet, esim. emokaupan mukana punkin leviämisen estäminen, ovat siksi tärkeitä. Täydentävä tapa ehkäistä jatkossa sisuspunkin tuhot on siirtyä varroapunkin torjunnassa menetelmiin, jotka tehoavat myös sisuspunkkiin, esim. muurahaishapon käyttöön. 